\title{
УДК 272 (476) \\ КУЛЬТУРНАЯ ПОЛИТИКА СОВЕТСКОЙ ВЛАСТИ В ЗАПАДНО-БЕЛОРУССКОМ РЕГИОНЕ В 1939-1941 Гг. И ЕЁ ВЛИЯНИЕ НА ХАРАКТЕР МЕЖЭТНИЧЕСКИХ ОТНОШЕНИЙ
}

\author{
Н. Н. КОВАЛЁВА
}

Брестский государственный технический университет, г. Брест, Беларусь

С установлением советской власти в 1939 году в западно-белорусском регионе радикально меняется направленность культурной политики. Если в начале XX века главной целью культурной политики властей была русификация, в межвоенный период - полонизация, то сейчас культурная политика подчинена решению задачи внедрения коммунистической идеологии, то есть имеет наднациональный характер. Однако её реализация существенно меняет характер межэтнических и межрелигиозных отношений в регионе.

Главным фактором, повлиявшим на изменение культурной политики, стала советизация, проявившаяся в создании сети советских учреждений культуры, введении советской системы образования, а также в изменении идейной направленности в работе общественных и культурных организаций. Советизация реализовывалась новыми органами власти, которые, в силу поставленных задач, должны были иметь иной социальный и национальный состав, причем главным критерием для выдвижения в органы власти становилось социальное происхождение, а не национальная принадлежность. В соответствии с духом коммунистической идеологии предполагалось утверждать равенство наций, устранив при этом привилегированное положение поляков и создав преимущества нациям, ранее подвергавшимся дискриминации (белорусам, украинцам, евреям). С пропагандистской целью ставка делалась на белорусизацию, хотя в БССР от политики белорусизации давно отказались.

Если в БССР в 1920-е годы политика белорусизации имела под собой серьёзную социальную базу в виде безусловного преобладания белорусско-язычного населения, то в Западной Беларуси ситуация была иной. По данным белорусских историков, в 1931 г. в Виленском, Новогрудском и Полесском воеводствах поляки составляли около $12 \%$ населения, украинцы - 5,8\%, евреи - около 9\%, литовцы - более $3 \%$, русские - $2 \%$, белорусы - 67\% [1, c. 370-371]. В городах преобладало польское и еврейское население. По данным переписи 1931 г., из 40605 жителей Бреста поляки составляли 13454 (33,1\%), украинцы - 1237 (3\%), евреи - 19693 (48,3\%), русские - 4951 (12,2\%), белорусы - 1370 (3,4\%) [2, л. 157]. Ввиду низкого образовательного уровня белорусов довольно значительным оказался процент евреев в государственных и хозяйственных органах, так как их уровень образования был, как правило, выше. Выдвижение евреев в органы государственного и хозяйственного руководства зачастую возбуждало недовольство поляков. Многие исследователи пишут о фактах еврейских погромов. Другие считают, что имело место проявление антисоветизма, который трактовался как антисемитизм [3, с. 40]. В значительной степени руководящие структуры комплектовались за счет так называемых «восточников» - переселенцев из восточной Беларуси и других районов СССР, которые руководству республики представлялись более благонадёжными. «Восточники» являлись в своём большинстве носителями русской культуры, среди которых даже этнические белорусы давно отказались от белорусского языка и, будучи научены горьким опытом контрбелорусизации, относились к белорусскому языку и белорусской культуре с осторожностью и даже с пренебрежением.

Появление нового контингента «восточников» в структуре населения региона стало проявлением одной из волн миграции периода 1939-1941 гг. Большое влияние на ситуацию в регионе оказало переселение эмигрантов (в основном евреев) из Польши, Германии, Литвы с началом Второй мировой войны и выселение части населения (в основном поляков) в восточные районы СССР. Динамику миграционных процессов можно проследить по изменению численности и национального состава населения Бреста. По данным переписи, 
проведённой немцами 20 июля 1941 года в Бресте, евреи составили 18 000, поляки - 15 000, представители других национальностей, в том числе белорусы, - 10 000, «восточники»8000 человек [4, л. 121].

Национальный аспект культурной политики реализовывался, прежде всего, через политику в области образования. Делая ставку на белорусизацию, руководство республики предполагало учитывать интересы и других этнических групп, создавая национальные школы (белорусские, русские, еврейские, польские и литовские) в зависимости от особенностей национальной структуры населения. В частности, в постановлении Брестского облисполкома от 19 декабря 1939 г. говорилось: «Считать, что основная масса школ в области должна быть белорусской. Одновременно в соответствии с национальным составом и желанием родителей открывать национальные школы (русские, еврейские, польские и украинские)» [5, л. 4].

В реализации задачи создания белорусской школы возникли серьёзные трудности. Вопервых, в регионе не было абсолютного преобладания белорусов; во-вторых, население не владело литературным белорусским языком, так как многие годы основным языком обучения был польский; в-третьих, у многих белорусов отсутствовало развитое национальное самосознание, особенно у белорусов-католиков; в-четвёртых, отсутствовало достаточное количество учителей, так как многие учителя, окончившие университеты, владевшие иностранными языками, не знали белорусского языка и имели неподходящее по советским меркам социальное происхождение. Эти учителя изгонялись из школы и зачастую депортировались. В результате чистки учительского состава в 1939/40 уч. году только в Брестской области не были допущены к работе в реорганизованной школе 250 учителей [6, с. 412]. На место изгнанных учителей из восточной Беларуси прибывали молодые комсомольцы и коммунисты, окончившие двухгодичные пединституты, не владевшие ни белорусским, ни польским языком.

И белорусские, и русские школы испытывали огромные трудности с обеспечением учебниками. Ситуацию с учебниками очень ярко отразил в своей книге «Империя» Ришард Капущинский: «В школе мы учим русский алфавит с первого урока. Начинаем с буквы «с». «Как это с "с"? - спрашивает кто-то из глубины класса. Начинать надо с "а"!» «Дети, говорит учитель унылым голосом (он поляк), посмотрите на обложку нашей книги. Какая первая буква на этой обложке? "С"!» Петрусь, который является белорусом, может прочитать всю надпись: Сталин "Вопросы ленинизма". Это единственная книга, по которой мы учим русский язык, единственная копия этой книги [7, с. 3].

В некоторых городах, в частности, в Гродно и Белостоке, при создании школ имели место вопиющие факты нарушения национального принципа. Ни в одной из средних школ в этих городах не осуществлялось обучение на польском языке, хотя поляки здесь численно преобладали. В этих городах процесс полонизации зашел достаточно далеко, и думается, что советская власть, делая ставку на белорусизацию, стремилась повернуть к белорусскому языку белорусов-католиков, которые привыкли считать польский язык родным. Действительно, в тех регионах, где католический костёл имел сильные позиции, полонизация шла более успешно. И, напротив, в регионах, где было сильно влияние православной церкви, польский язык и культура получили меньшее распространение, например, в Западном Полесье. Белорусский исследователь В.В. Шейбак считает, что полонизация на Брестчине оказалась куда менее эффективной, чем на Гродненщине. «На Брестчине конфессиональный фактор не мог быть широко использован для полонизации, так как в Полесском воеводстве, судя по результатам переписи 1931 г., в конфессиональной структуре населения православные составляли подавляющее большинство - 77,4\%, католики - $11 \%$, иудеи - $10 \%$ » 8, с. 27$]$.

Не удивительно, что Советская власть, борясь с последствиями полонизации, оказывала давление на римско-католическую церковь, но, учитывая высокую степень религиозности населения западно-белорусского региона, проявляла большую терпимость к православной церкви, чем в БССР, что проявлялось в сокращении масштабов антицерковных акций и использовании хорошо контролируемой Московской Патриархии, как средства советизации [9, с. 350-351]. 
В Западном Полесье, кроме белорусского, традиционно был распространён ещё и украинский язык. По официальным данным, в Западной Беларуси было создано 49 украинских школ [1, с. 462]. К сожалению, мы не располагаем данными, где именно существовали эти школы. Думается, что учитывая наличие мощного национального движения на Украине, где уже разворачивалась деятельность Организации украинских националистов (ОУН), создававшей свои структуры и в Западном Полесье, Советская власть не стремилась поощрять развитие национального самосознания у украинцев Западной Беларуси.

Белорусизация польских и еврейских школ продолжалась менее года. Руководство областных и районных отделов народного образования под предлогом бесперспективности национальных школ и, исходя из того, что основным языком преподавания должен быть тот, который понятен большинству школьников, с 1940 года начало процесс реорганизации белорусских школ в русские. В городах белорусско-язычные школы вообще не получили распространения. Например, «по состоянию на 1 сентября 1940 года в Бресте было 5 начальных (2 еврейские, по одной русской, польской и белорусской), 12 неполных средних (4 русских, 3 польских, 3 еврейских и 2 белорусских) и 7 средних школ (4 русских, 2 польских и 1 еврейская) [10]. Еврейские школы, перед которыми была поставлена проблема выбора языка обучения (идиш или русский), отказывались от преподавания на идише [11, с. 158-159]. Но в некоторых польских школах преподавание ряда предметов перевели обратно на польский язык.

В целом, в 1940 году отношение к польской культуре стало более лояльным. Это объясняется не только тем, что антисоветски настроенная часть поляков к этому времени уже была депортирована из Западной Беларуси, но и изменением внешнеполитической ситуации. В 1939 году большинство газет в регионе издавались на белорусском и русском языках. Осенью 1940 года была создана в Белоруской ССР газета на польском языке «Sztandar Wolności» («Знамя свободы»). В 1940-1941 годах в Западной Белоруссии на польском языке выходили две республиканские и шесть местных газет [12, с.73]. И даже процесс переименования улиц, в результате которого большинство из них обрело названия, связанные с советской историей, не затронул улицу А. Мицкевича в Бресте. Однако, и в школьном образовании, и в издании газет, в деятельности театров и кинотеатров всё явственнее проявлялся крен к использованию русского языка.

Таким образом, культурная политика большевиков в западно-белорусском регионе имела результатом советизацию. В то же время она оказала существенное влияние на изменение характера динамики культур. В результате недостаточного учёта национальной специфики региона ситуация полного господства польской культуры, дополняемая жестким неприятием иных этнических культур, сменилась ситуацией господства русской культуры, отождествляемой с советской, настороженным отношением к польской и, можно сказать, безразличным отношением к культуре других национальных меньшинств. В регионе практически не отмечалось сопротивления советизации (в отличие от западно-украинского региона), так как Советская власть оказывала поддержку этническим группам, которые ранее находились в угнетённом состоянии, и провела превентивные меры по высылке поляков. Однако, если в западно-украинском регионе в 1939-1941 гг. одновременно с советизацией действительно была проведена украинизация [13, с.28], в западно-белорусском регионе белорусизация не состоялась. Напротив, политика властей вела к дальнейшему размыванию этнического сознания у белорусов, выдвигая на первый план градацию не по национальному, a по социальному признаку, и утверждая приоритет не национальных, а классовых интересов. Политика большевиков на землях Западной Беларуси не ликвидировала, а лишь обострила межнациональное противостояние. Следует признать, что так и не удалось преодолеть конфронтационного характера в отношениях поляков (титульного этноса в польском государстве, однако, находящегося в западно-белорусских землях в численном меньшинстве) и белорусов (коренного большинства населения). Имело место обострение польско-еврейского противостояния, которое часто трактовалось как проявление антисоветизма. 


\section{Литература}

1. Гісторыя Беларусі: у 6 т. / А. Вабішчэвіч [i інш.]; рэдкал. М. Касцюк (гал. рэдактар) [i інш.]. - Мінск : Экаперспектыва, 2006. - Т 5 : Беларусь у 1917-1945 гг. - 613 с.

2. ГАБО. - Фонд 1. - ОП. 1. - Д. 595.

3. Milewski Jan Jerzy. 17 września 1939 r. - zderzenie i dialog pamięci: polskiej, białoruskiej i żydowskiej // Восень 1939 года ў гістарычнай традыцыі і вуснай гісторыі / Пад рэд. д-ра гіст. н. А. Смаленчука. - Мінск : Зміцер Колас, 2015. - 288 с.

4. ГАБО. - Фонд 1. - ОП. 28. - Д. 91.

5. ГАБО. - Фонд 815. - Оп. 1. - Д. 1а.

6. Трофимчик, А. В. Меры по ликвидации оппозиционных настроений и антисоветской деятельности в школах западных областей БССР (1939-1941) // Западная Белоруссия и Западная Украина в 1939-1941 гг. : люди, события, документы. - СПб. : Алетейя, 2011. 424 с.: ил.

7. Kapuscinski Ryszard Imperium // [Электронный ресурс]. - Режим доступа : RuLit_Me_563667.rtf.zip.-Дата доступа : 19.09. 2019

8. Шейбак, В. В. Этническая история западного Полесья (Брестчины) // Этнокультурные процессы Западного Полесья (Брестчины) в прошлом и настоящем / А. Вл. Гурко [и др.]; науч. ред. А. Викт. Гурко; Нац. акад. наук Беларуси, Центр исслед. белорус, культуры, языка и лит., Ин-т этнографии и фольклора им. Кондрата Крапивы. - Минск : Беларуская навука, 2020. - 621 с.: ил.

9. Цымбал, А. Г. Положение православной церкви в Западной Белоруссии в 1939-1941 годах // Западная Белоруссия и Западная Украина в 1939-1941 гг. : люди, события, документы. - СПб. : Алетейя, 2011. - 424 с.: ил.

10. Карпович, О. Советская власть в Западной Беларуси 1939 г. : образование. [Электронный ресурс]. - Режим доступа : Виртуальный Брест. - Дата доступа : 30.10.2015.

11. Карпенкина, Я. В. Советизируя евреев: из истории советской образовательной политики в Западной Белоруссии, 1939-1941 год // Российская история. - 2017. - № 5.

12. Милевский, Я. Е. Включение «Западной Белоруссии» в СССР (1939-1941) : новая точка зрения // Западная Белоруссия и Западная Украина в 1939-1941 гг. : люди, события, документы. - СПб. : Алетейя, 2011. - 424 с.: ил.

13. Борисёнок, Е. Ю. Концепции «украинизации» и их реализация в национальной политике в государствах восточноевропейского региона (1918-1941) : автореферат на соискание учёной степени доктора исторических наук. - Институт славяноведения РАН, 2016.

Автор статьи рассматривает влияние культурной политики Советскойвласти, реализуемой в западных областях БССР в 1939-1941 гг., на характер межэтнических и межрелигиозных отношений в регионе. Делается вывод, что культурная политика, подчинённая решению задачи внедрения коммунистической идеологии, вызвала изменения в характере динамики культур и обострила межнациональные противоречия.

The author of the article examines the influence of the cultural policy of the Soviet power, implemented in the western regions of the BSSR in 1939-1941, on the nature of interethnic and interreligious relations in the region. It is concluded that cultural policy, subordinate to the solution of the problem of introducing communist ideology, caused changes in the nature of the dynamics of cultures and exacerbated ethnic contradictions. 